\title{
IL-1R2 Polymorphisms and its Interaction Associates With Osteoporosis Susceptibility in Chinese Han Population
}

Research article

Keywords:

Posted Date: September 23rd, 2020

DOI: https://doi.org/10.21203/rs.3.rs-25428/v2

License: (9) This work is licensed under a Creative Commons Attribution 4.0 International License.

Read Full License 


\section{Abstract}

The authors have requested that this preprint be withdrawn due to erroneous posting.

\section{Full Text}

The authors have withdrawn this preprint from Research Square. 